\title{
Employee Performance Assessment for Promotion with the Topsis Method in Senayan Apartments Jakarta
}

\author{
Sunarti \\ Universitas Bina Sarana Informatika \\ Jakarta, Indonesia \\ Sunarti.sni@bsi.ac.id
}

\begin{abstract}
Apartment Senayan Jakarta is a company engaged in rental services. Job promotion is carried out every year. Job promotion makes motivated employees work well and enthusiasm in selfdevelopment to improve the quality of performance. Performance evaluation as material for employee evaluation for promotion in Senayan Apartment Jakarta by utilizing the Technique for Order Preference method by Similarity of Ideal Solution (Topsis). This method can show evaluation ranking from highest to lowest by ranking alternatives in the form of employee data and dynamic criteria. The purpose of this study is the selection of quality employee performance for promotion based on the specified criteria. Based on the data sample used as many as 14 employees, the results of the assessment are based on rank, ie employees on behalf of Ridan get the first rank with a value of 0.50 .
\end{abstract}

Keywords- Performance assessment; Position Promotion; Topsis method

\section{INTRODUCTION}

Assessment of the quality of employee performance is very useful to help companies see and determine employees whose performance is good by looking at the relevance of each of the specified criteria (Nurhayati, 2017). Research conducted at the Senayan Jakarta Apartment to assess the quality of employee performance for promotion is carried out every year. In evaluating the quality of employee performance there are seventeen criteria that must be met by its employees. The criteria in this study are job knowledge, quality of work, productivity, ability, communication, achievement/management, time, logic, compliance, cost awareness, teamwork, temperament, responsibility, work ethics, flexibility, innovation, service orientation, dedication to work.

The problem in assessing the quality of employee performance for promotion in Senayan Jakarta Apartments conducted every year is that there are parts that must be met and cannot be empty, routine activities on performance appraisal every year and to strengthen teamwork. In the promotion carried out a lot of specified criteria, this results in problems faced by the leadership in assessing the quality of employee performance for promotion. Many of the existing criteria will cause criteria that are not easily measured, there is no weighting number and calculation using the manual system which results in the agreement taken is still subjective.

To solve the problem, the authors used the Technique for Order Preference by Similarity of Ideal Solution (Topsis) method, in this method to share the results to show evaluation ranking from highest to lowest and in the criteria, it is dynamic to help provide the best alternative to companies in making decisions (Yusnita, Salmon, \& Ramadhan, 2015), besides this method can estimate and provide the final value of the rating that has been ranked to determine the employees to be promoted (Mallu, 2015). The Technique for Order Preference method by Similarity of Ideal Solution to evaluate the level of employee performance supports the company and shows that qualified employees work well and take into account each number of weighting points on each criterion utilized (Nurhayati, 2017). The Topsis method for assessing employee performance, so that managers can know the attitude of each subordinate and can evaluate the performance of employees so that employees can work well (Kurniawan, 2015). The Topsis method ranks students in accordance with government regulations, can provide input to faculty leaders for the basis of decision making and is used to determine the best 
graduates in the activity prior to graduation (Herawatie \& Wuryanto, 2017).

The purpose of this study is to use the Topsis method to help leaders in Senayan Jakarta Apartments in choosing the quality of employee performance for more effective job promotion based on existing criteria with good performance.

\section{LITERATURE REVIEW}

\section{A. Decision Support Systems}

Decision Support Systems are usually built to provide solutions to a problem. Its characteristics are supporting the decision-making process of an organization or company, the existence of a human interface / machine where humans still hold control of the decision-making process, supporting decision makers to discuss systematic, semi-systematic problems and supporting multiply interconnected decisions, having dialogue capacity to obtain information as needed, has a subsystem that is integrated in such a way that it can function as a system unity, and has the first two parts, namely data and models (Nofriansyah, 2015).

The purpose of this study is to assist in making decisions on structured problems, providing support at the manager's discretion and not intended to replace the functions of managers, increasing the effectiveness of decisions taken more than improving efficiency, the speed of computer computing allows decision makers to compute quickly with low costs and increased productivity building a group of decision makers, especially experts, can be very expensive (Nofriansyah, 2015).

\section{B. Position Promotion}

Position Promotion is a leader raising an employee's position or an employee one level higher than his previous position and accepting power and responsibility greater than his previous responsibilities, after the employee or employee concerned goes through an evaluation or assessment process and is declared eligible to be promoted to a higher level high (Afandi, 2016)

Based on (Afandi, 2016) the objectives of the promotion are:

1) Convey recognition of the results of good performance

2) In social status the higher and the greater the income.

3) Stimulating employees to work more spiritually, obediently, orderly and increase their performance better
4) Making opportunities for employees to improve their creativity and better innovation for optimal benefits to the company

5) Can fulfill the vacant position because the official is out so that the position is not vacant then other employees are promoted.

\section{Technique for Order Preference by Similarity of Ideal Solution (TOPSIS)}

The method used is used to provide output by showing the evaluation level from the highest to the lowest and in its criteria is dynamic to support the best alternative assessment (Yusnita et al., 2015). The levels of the Topsis method are (Nofriansyah, 2015):

1. Describe the alternative $(\mathrm{m})$ and criteria $(\mathrm{n})$ in a matrix, where $\mathrm{Xij}$ is a measurement of choice from the $\mathrm{i}$-alternative and $\mathrm{j}$-criteria.

$$
D=\begin{array}{llll}
X_{11} & X_{12} & \ldots & X_{1 n} \\
X_{21} & X_{22} & \ldots & X_{2 n} \\
X_{m 1} & X_{m 1} & \ldots & X_{m n}
\end{array}
$$

2. Make an $\mathrm{R}$ matrix that is a normalized decision matrix. Where the value of each matrix element is obtained from equation 2 .

$$
r i j=\frac{x_{i j}}{\sqrt{\sum_{i=1}^{m} x_{i j}^{2}}}
$$

3. Form a weighting on a normalized matrix.

$$
D=\begin{array}{ccc}
W_{1} r_{11} & W_{1} r_{12} & W_{n} r_{n} \\
W_{2} r_{21} & \ldots \ldots & \ldots \ldots \\
W_{j} r_{m 1} & W_{j} r_{m 2} & W_{1} r_{m m}
\end{array}
$$

4. Describe the assessment for positive ideal solutions and negative ideal solutions. The ideal solution is described as $\mathrm{A}^{+}$, and for an ideal negative solution denoted A-.

$$
\begin{aligned}
\mathrm{A}^{+} & =\left[\begin{array}{llll}
Y_{1}^{+} & Y_{2}^{+} & \ldots & Y_{n}^{+}
\end{array}\right] \\
\mathrm{A}^{-} & =\left[\begin{array}{llll}
Y_{1}^{-} & Y_{2}^{-} & \ldots & Y_{n}^{-}
\end{array}\right]
\end{aligned}
$$

5. Describe the distance from an alternative to a positive ideal solution

1) Calculation of positive ideal solutions can be seen in equation 6 :

$$
\mathrm{Si}^{+}=\sqrt{\sum_{i=1}^{n}\left(Y_{i}^{+}-Y_{i j}+\right)^{2}}
$$

With $\mathrm{I}=1,2,3, \ldots, \mathrm{n}$

2) Calculation of negative ideal solutions can be seen in equation 7 :

$$
\begin{aligned}
& \mathrm{Si}^{+}=\sqrt{\sum_{i=1}^{n}\left(V_{i j}-V_{j}-\right)^{2}} \\
& \text { With } \mathrm{I}=1,2,3, \ldots, \mathrm{n}
\end{aligned}
$$

6. Describe preference values for each alternative. To determine the ranking of each available alternative, it is necessary to calculate the prefix value of each alternative.

$$
V_{i}^{+}=\frac{s_{i}^{-}}{S_{i}^{+}+S_{i}^{-}}
$$

Where $0<C_{i}^{+}<1$ And $\mathrm{i}=1,2,3, \ldots, \mathrm{m}$ 
After obtaining the $\mathrm{Ci}^{+}$value, the alternative can be ranked based on the order of $\mathrm{Ci}^{+}$. Based on these ranking results, it can be seen that the best alternative is an alternative that has the shortest distance from the ideal solution and the farthest distance from the negative ideal solution.

\section{Type of Research}

This study included descriptive research. This method is a way of examining status in groups of humans, objects, in sets of circumstances, forms of ideas, or events in the present. The purpose of the research is to create a descriptive, structured and valid research for the truth and the relationship between the circumstances under investigation (Sugiyono, 2016).

This study uses the Topsis method on promotion in Senayan Jakarta Apartments to improve the quality of performance by ranking.

\section{E. Variables and measurements}

1. Alternative Variable $\left(A_{i}\right)$

The alternative variable in this study was to use data samples of 14 employees at the Senayan Jakarta apartment with the names of employees Dedy Iswandi, Ari Purwanto, Ridan, Yustiadi Tresna, Anggun Eko, Maulana Yusuf, Metro Ahmadi, Rudi Hartana, Cecep Mulyadi, Dini Apriyani, Intan, Danang Dwi, Rahayu Setiorini, Bayu Purnomo.

\section{Criteria Variable $(\mathrm{Cj})$}

The criteria variable used in this study consisted of job knowledge, quality of work, productivity, ability, communication, achievement/management, time, logic, compliance, cost awareness, teamwork, temperament, responsibility, work ethics, flexibility, innovation, service orientation, dedication to work. All criteria are assumed to be a benefit.

The stages of research consist of two stages, namely the stages of data collection and the stages of data analysis.

\section{Data Collection}

In this method, the writing collects data using: (1) Primary Data is done by (a) Library Study, at this stage, the author explores the concept of research through literature based on previous studies to be used as supporting studies on research topics that the author did. (b) Observation, at this stage data collection, was carried out through direct observation at the Senayan Apartment Jakarta, then processing observational data, to be analyzed with the Topsis Method (c) Interview, the author conducted an interview with Senayan Apartment supervisor Jakarta. (2) Secondary data comes from collecting and identifying and processing written data in the form of books and journals relating to the issues discussed.

\section{Data Analysis Method}

Data analysis in research is very important in research methodology because by analyzing, the data can be processed, processed and given meaning and meaning to solve the problems that occur. In this study using the Topsis method. This method takes into account qualitative and quantitative matters. In this study, the authors used quantitative data.

\section{F. Data Analysis Methods and Techniques}

The data analysis method used in this study was the Topsis method. This method is used in promotion to improve the quality of employee performance every year at the Senayan Apartment in Jakarta.

The analysis technique in this study uses quantitative data analysis techniques, namely data analysis techniques using mathematical rules for numerical/numeric data.

\section{DISCUSSION}

The following are the results of research conducted at the Senayan Apartment Jakarta with the Technique for Order Preference by Similarity of Ideal Solution (Topsis) method using a data sample of 14 employees with the names of employees Dedy Iswandi (A1), Ari Purwanto (A2), Ridan (A3), Yustiadi Tresna (A4), Anggun Eko (A5), Maulana Yusuf (A6), Metro Ahmadi (A7), Rudi Hartana (A8), Cecep Mulyadi (A9), Dini Apriyani (A10), Intan (A11), Danang Dwi (A12), Rahayu Setiorini (A13), Bayu Purnomo (A14).

There are 17 criteria used to assess the quality of employee performance for job promotion are job knowledge, quality of work, productivity, ability, communication, achievement/management, time, logic, compliance, cost awareness, teamwork, temperament, responsibility, work ethics, flexibility, innovation, service orientation, dedication to work. All criteria are assumed to be a benefit. The level of importance of each criterion is assessed in the range of 1 to 5 , which is $1=$ very bad, $2=$ bad, $3=$ sufficient, 4 $=$ good and 5=very good. The sample value of employee data in each alternative for all criteria can be seen in table 1 . Using equation 1. 
TABLE 1 ALTERNATIVE TO THE MATCH CRITERIA

\begin{tabular}{|c|c|c|c|c|c|c|c|c|c|c|c|c|c|c|c|c|c|}
\hline Alternative & P1 & P2 & P3 & P4 & P5 & P6 & P7 & P8 & P9 & P10 & P11 & P12 & P13 & P14 & P15 & P16 & P17 \\
\hline A1 & 4 & 3 & 4 & 3 & 5 & 3 & 3 & 3 & 4 & 3 & 3 & 3 & 5 & 3 & 4 & 5 & 3 \\
\hline $\mathrm{A} 2$ & 3 & 4 & 3 & 3 & 3 & 4 & 3 & 3 & 3 & 4 & 3 & 3 & 3 & 4 & 3 & 3 & 4 \\
\hline A3 & 3 & 5 & 4 & 4 & 4 & 5 & 4 & 4 & 4 & 4 & 4 & 5 & 4 & 4 & 4 & 4 & 4 \\
\hline A5 & 4 & 5 & 5 & 5 & 3 & 5 & 5 & 4 & 5 & 5 & 5 & 4 & 4 & 5 & 5 & 3 & 3 \\
\hline A6 & 4 & 3 & 5 & 3 & 5 & 3 & 5 & 3 & 3 & 3 & 3 & 3 & 5 & 3 & 3 & 5 & 3 \\
\hline A7 & 3 & 4 & 5 & 3 & 3 & 4 & 3 & 3 & 3 & 4 & 3 & 3 & 3 & 4 & 3 & 3 & 4 \\
\hline A9 & 4 & 3 & 4 & 4 & 5 & 4 & 5 & 3 & 4 & 3 & 4 & 3 & 5 & 3 & 4 & 4 & 3 \\
\hline A10 & 4 & 4 & 4 & 5 & 5 & 3 & 4 & 4 & 4 & 5 & 5 & 4 & 4 & 5 & 5 & 3 & 3 \\
\hline A11 & 3 & 4 & 3 & 3 & 3 & 4 & 3 & 3 & 3 & 4 & 5 & 5 & 3 & 4 & 3 & 3 & 4 \\
\hline A12 & 3 & 5 & 4 & 4 & 4 & 4 & 4 & 4 & 4 & 4 & 4 & 5 & 4 & 5 & 4 & 4 & 4 \\
\hline A13 & 5 & 3 & 5 & 4 & 4 & 5 & 4 & 4 & 4 & 5 & 4 & 3 & 4 & 5 & 4 & 4 & 3 \\
\hline A14 & 4 & 4 & 4 & 5 & 5 & 5 & 4 & 4 & 5 & 5 & 5 & 4 & 4 & 5 & 5 & 3 & 3 \\
\hline
\end{tabular}

From table 1 the matrix of a the decision is obtained, as follows:

$$
\left(\begin{array}{lllllllllllllllll}
4 & 3 & 4 & 3 & 5 & 3 & 3 & 3 & 4 & 3 & 3 & 3 & 5 & 3 & 4 & 5 & 3 \\
3 & 4 & 3 & 3 & 3 & 4 & 3 & 3 & 3 & 4 & 3 & 3 & 3 & 4 & 3 & 3 & 4 \\
3 & 5 & 4 & 4 & 4 & 5 & 4 & 4 & 4 & 4 & 4 & 5 & 4 & 4 & 4 & 4 & 4 \\
5 & 5 & 4 & 5 & 5 & 5 & 5 & 4 & 5 & 3 & 4 & 3 & 4 & 3 & 4 & 4 & 5 \\
4 & 5 & 5 & 5 & 3 & 5 & 5 & 4 & 5 & 5 & 5 & 4 & 4 & 5 & 5 & 3 & 3 \\
4 & 3 & 5 & 3 & 5 & 3 & 5 & 3 & 3 & 3 & 3 & 3 & 5 & 3 & 3 & 5 & 3 \\
3 & 4 & 5 & 3 & 3 & 4 & 3 & 3 & 3 & 4 & 3 & 3 & 3 & 4 & 3 & 3 & 4 \\
3 & 4 & 4 & 4 & 4 & 4 & 4 & 4 & 4 & 4 & 4 & 5 & 4 & 4 & 4 & 4 & 4 \\
4 & 3 & 4 & 4 & 5 & 4 & 5 & 3 & 4 & 3 & 4 & 3 & 5 & 3 & 4 & 4 & 3 \\
4 & 4 & 4 & 5 & 5 & 3 & 4 & 4 & 4 & 5 & 5 & 4 & 4 & 5 & 5 & 3 & 3 \\
3 & 4 & 3 & 3 & 3 & 4 & 3 & 3 & 3 & 4 & 5 & 5 & 3 & 4 & 3 & 3 & 4 \\
3 & 5 & 4 & 4 & 4 & 4 & 4 & 4 & 4 & 4 & 4 & 5 & 4 & 5 & 4 & 4 & 4 \\
5 & 3 & 5 & 4 & 4 & 5 & 4 & 4 & 4 & 5 & 4 & 3 & 4 & 5 & 4 & 4 & 3 \\
4 & 4 & 4 & 5 & 5 & 5 & 4 & 4 & 5 & 5 & 5 & 4 & 4 & 5 & 5 & 3 & 3
\end{array}\right)
$$

From the decision matrix then the normalized matrix is calculated, the calculation uses equation 2 . Then the normalized matrix is obtained as follows:

TABLE 2 NORMALISATION MATRIX

\begin{tabular}{|c|c|c|c|c|c|c|c|c|c|c|c|c|c|c|c|c|c|}
\hline Alternative & $\mathrm{P} 1$ & $\mathrm{P} 2$ & P3 & $\mathrm{P} 4$ & P5 & P6 & P7 & P8 & P9 & $\mathrm{P} 10$ & P11 & $\mathrm{P} 12$ & P13 & P14 & P15 & P16 & P17 \\
\hline A1 & 0,28 & 0,20 & 0,26 & 0,20 & 0,32 & 0,19 & 0,20 & 0,22 & 0,27 & 0,20 & 0,20 & 0,21 & 0,33 & 0,19 & 0,27 & 0,35 & 0,22 \\
\hline $\mathrm{A} 2$ & 0,21 & 0,26 & 0,19 & 0,20 & 0,19 & 0,25 & 0,20 & 0,22 & 0,20 & 0,26 & 0,20 & 0,21 & 0,20 & 0,26 & 0,20 & 0,21 & 0,29 \\
\hline A3 & 0,21 & 0,33 & 0,26 & 0,27 & 0,25 & 0,32 & 0,26 & 0,30 & 0,27 & 0,26 & 0,26 & 0,34 & 0,26 & 0,26 & 0,27 & 0,28 & 0,29 \\
\hline A4 & 0,35 & 0,33 & 0,26 & 0,33 & 0,32 & 0,32 & 0,33 & 0,30 & 0,33 & 0,20 & 0,26 & 0,21 & 0,26 & 0,19 & 0,27 & 0,28 & 0,37 \\
\hline A5 & 0,28 & 0,33 & 0,32 & 0,33 & 0,19 & 0,32 & 0,33 & 0,30 & 0,33 & 0,33 & 0,33 & 0,28 & 0,26 & 0,32 & 0,33 & 0,21 & 0,22 \\
\hline A6 & 0,28 & 0,20 & 0,32 & 0,20 & 0,32 & 0,19 & 0,33 & 0,22 & 0,20 & 0,20 & 0,20 & 0,21 & 0,33 & 0,19 & 0,20 & 0,35 & 0,22 \\
\hline A7 & 0,21 & 0,26 & 0,32 & 0,20 & 0,19 & 0,25 & 0,20 & 0,22 & 0,20 & 0,26 & 0,20 & 0,21 & 0,20 & 0,26 & 0,20 & 0,21 & 0,29 \\
\hline A8 & 0,21 & 0,26 & 0,26 & 0,27 & 0,25 & 0,25 & 0,26 & 0,30 & 0,27 & 0,26 & 0,26 & 0,34 & 0,26 & 0,26 & 0,27 & 0,28 & 0,29 \\
\hline A9 & 0,28 & 0,20 & 0,26 & 0,27 & 0,32 & 0,25 & 0,33 & 0,22 & 0,27 & 0,20 & 0,26 & 0,21 & 0,33 & 0,19 & 0,27 & 0,28 & 0,22 \\
\hline A10 & 0,28 & 0,26 & 0,26 & 0,33 & 0,32 & 0,19 & 0,26 & 0,30 & 0,27 & 0,33 & 0,33 & 0,28 & 0,26 & 0,32 & 0,33 & 0,21 & 0,22 \\
\hline A11 & 0,21 & 0,26 & 0,19 & 0,20 & 0,19 & 0,25 & 0,20 & 0,22 & 0,20 & 0,26 & 0,33 & 0,34 & 0,20 & 0,26 & 0,20 & 0,21 & 0,29 \\
\hline A12 & 0,21 & 0,33 & 0,26 & 0,27 & 0,25 & 0,25 & 0,26 & 0,30 & 0,27 & 0,26 & 0,26 & 0,34 & 0,26 & 0,32 & 0,27 & 0,28 & 0,29 \\
\hline A13 & 0,35 & 0,20 & 0,32 & 0,27 & 0,25 & 0,32 & 0,26 & 0,30 & 0,27 & 0,33 & 0,26 & 0,21 & 0,26 & 0,32 & 0,27 & 0,28 & 0,22 \\
\hline A14 & 0,28 & 0,26 & 0,26 & 0,33 & 0,32 & 0,32 & 0,26 & 0,30 & 0,33 & 0,33 & 0,33 & 0,28 & 0,26 & 0,32 & 0,33 & 0,21 & 0,22 \\
\hline
\end{tabular}



it gets:

After getting the R matrix, the next step is to calculate the weighted normalized matrix using equation 3 , then

\begin{tabular}{|c|c|c|c|c|c|c|c|c|c|c|c|c|c|c|c|c|c|}
\hline Alternative & P1 & P2 & P3 & P4 & P5 & P6 & P7 & P8 & P9 & P10 & P11 & P12 & P13 & P14 & P15 & P16 & P17 \\
\hline Weight & 5 & 4 & 5 & 5 & 3 & 4 & 5 & 5 & 4 & 3 & 4 & 5 & 5 & 4 & 5 & 5 & 5 \\
\hline A1 & 1,41 & 0,79 & 1,28 & 1 & 0,95 & 0,76 & 0,98 & 1,11 & 1,07 & 0,59 & 0,79 & 1,03 & 1,65 & 0,77 & 1,34 & 1,77 & 1,11 \\
\hline A2 & 1,06 & 1,05 & 0,96 & 1 & 0,57 & 1,02 & 0,98 & 1,11 & 0,80 & 0,79 & 0,79 & 1,03 & 0,99 & 1,03 & 1,00 & 1,06 & 1,47 \\
\hline A3 & 1,06 & 1,31 & 1,28 & 1,33 & 0,76 & 1,27 & 1,31 & 1,48 & 1,07 & 0,79 & 1,05 & 1,72 & 1,32 & 1,03 & 1,34 & 1,41 & 1,47 \\
\hline A4 & 0,50 & 0,26 & 0,33 & 0,33 & 0,30 & 0,24 & 0,32 & 0,33 & 0,36 & 0,12 & 0,21 & 0,21 & 0,43 & 0,15 & 0,36 & 0,50 & 0,41 \\
\hline A5 & 0,30 & 0,34 & 0,30 & 0,33 & 0,11 & 0,32 & 0,32 & 0,33 & 0,27 & 0,26 & 0,26 & 0,28 & 0,26 & 0,33 & 0,34 & 0,23 & 0,33 \\
\hline A6 & 0,30 & 0,26 & 0,41 & 0,27 & 0,24 & 0,24 & 0,43 & 0,33 & 0,22 & 0,16 & 0,21 & 0,36 & 0,43 & 0,20 & 0,27 & 0,50 & 0,33 \\
\hline A7 & 0,11 & 0,07 & 0,10 & 0,07 & 0,06 & 0,06 & 0,06 & 0,07 & 0,07 & 0,03 & 0,04 & 0,04 & 0,09 & 0,04 & 0,07 & 0,11 & 0,12 \\
\hline A8 & 0,06 & 0,09 & 0,08 & 0,09 & 0,03 & 0,08 & 0,08 & 0,10 & 0,07 & 0,07 & 0,07 & 0,10 & 0,07 & 0,09 & 0,09 & 0,06 & 0,10 \\
\hline A9 & 0,08 & 0,05 & 0,10 & 0,07 & 0,08 & 0,06 & 0,14 & 0,07 & 0,06 & 0,03 & 0,05 & 0,07 & 0,14 & 0,04 & 0,07 & 0,14 & 0,07 \\
\hline A10 & 0,03 & 0,02 & 0,03 & 0,02 & 0,02 & 0,01 & 0,02 & 0,02 & 0,02 & 0,01 & 0,01 & 0,01 & 0,02 & 0,01 & 0,02 & 0,02 & 0,03 \\
\hline A11 & 0,01 & 0,02 & 0,01 & 0,02 & 0,01 & 0,02 & 0,02 & 0,02 & 0,01 & 0,02 & 0,02 & 0,03 & 0,01 & 0,02 & 0,02 & 0,01 & 0,03 \\
\hline A12 & 0,02 & 0,02 & 0,03 & 0,02 & 0,02 & 0,02 & 0,04 & 0,02 & 0,02 & 0,01 & 0,01 & 0,03 & 0,04 & 0,01 & 0,02 & 0,04 & 0,02 \\
\hline A13 & 0,01 & 0,00 & 0,01 & 0,01 & 0,00 & 0,00 & 0,00 & 0,01 & 0,01 & 0,00 & 0,00 & 0,00 & 0,01 & 0,00 & 0,01 & 0,01 & 0,01 \\
\hline A14 & 0,00 & 0,01 & 0,00 & 0,01 & 0,00 & 0,01 & 0,00 & 0,01 & 0,00 & 0,01 & 0,01 & 0,01 & 0,00 & 0,01 & 0,01 & 0,00 & 0,01 \\
\hline Max & 1,41 & 1,31 & 1,28 & 1,33 & 0,95 & 1,27 & 1,31 & 1,48 & 1,07 & 0,79 & 1,05 & 1,72 & 1,65 & 1,03 & 1,34 & 1,77 & 1,47 \\
\hline Min & 1,06 & 0,79 & 0,96 & 1 & 0,57 & 0,76 & 0,98 & 1,11 & 0,80 & 0,59 & 0,79 & 1,03 & 0,99 & 0,77 & 1,00 & 1,06 & 1,11 \\
\hline
\end{tabular}

From the weighted normalized matrix, the ideal positive $\left(\mathrm{A}^{+}\right)$and negative $\left(\mathrm{A}^{-}\right)$values can be seen as follows:

TABLE 4 POSITIVE IDEAL SOLUTION (A ${ }^{+}$DAN NEGATIVE (A-)

\begin{tabular}{|l|c|c|c|c|c|c|c|c|c|c|c|c|c|c|c|c|c|}
\hline Alternative & P1 & P2 & P3 & P4 & P5 & P6 & P7 & P8 & P9 & P10 & P11 & P12 & P13 & P14 & P15 & P16 & P17 \\
\hline positive & 1,77 & 1,77 & 1,77 & 1,77 & 1,77 & 1,77 & 1,77 & 1,77 & 1,77 & 1,77 & 1,77 & 1,77 & 1,77 & 1,77 & 1,77 & 1,77 & 1,47 \\
\hline negative & 0,57 & 0,57 & 0,57 & 0,57 & 0,57 & 0,59 & 0,59 & 0,59 & 0,59 & 0,59 & 0,77 & 0,77 & 0,77 & 0,77 & 1 & 1,06 & 1,11 \\
\hline
\end{tabular}

After getting the ideal solution, the next step is to determine the distance from an alternative positive and negative ideal solution, the data can be seen in Table 5.

TABLE 5 DISTANCE WEIGHTED VALUE OF POSITIVE AND NEGATIVE

\begin{tabular}{|c|c|c|}
\hline Alternative & positive & negative \\
\hline A1 & 3,06 & 1,93 \\
\hline A2 & 3,31 & 1,35 \\
\hline A3 & 2,39 & 2,38 \\
\hline A4 & 5,95 & 1,78 \\
\hline A5 & 6,04 & 1,90 \\
\hline A6 & 5,99 & 1,83 \\
\hline A7 & 6,93 & 2,73 \\
\hline A8 & 6,90 & 2,71 \\
\hline A9 & 6,90 & 2,70 \\
\hline A10 & 7,14 & 2,94 \\
\hline A11 & 7,15 & 2,94 \\
\hline A12 & 7,13 & 2,93 \\
\hline A13 & 7,20 & 3,00 \\
\hline A14 & 7,20 & 3,00 \\
\hline
\end{tabular}

Next is to calculate the preference value for each alternative, can be seen in table 6 .
TABLE 6 THE VALUE OF THE PREFERENCE

\begin{tabular}{|c|c|c|c|}
\hline & & & \\
Alternative & Positive & Negative & Preferences \\
\hline A1 & 3,06 & 1,93 & 0,39 \\
\hline A2 & 3,31 & 1,35 & 0,29 \\
\hline A3 & 2,39 & 2,38 & 0,50 \\
\hline A4 & 5,95 & 1,78 & 0,23 \\
\hline A5 & 6,04 & 1,90 & 0,24 \\
\hline A6 & 5,99 & 1,83 & 0,23 \\
\hline A7 & 6,93 & 2,73 & 0,28 \\
\hline A8 & 6,90 & 2,71 & 0,28 \\
\hline A9 & 6,90 & 2,70 & 0,28 \\
\hline A10 & 7,14 & 2,94 & 0,29 \\
\hline A11 & 7,15 & 2,94 & 0,29 \\
\hline A12 & 7,13 & 2,93 & 0,29 \\
\hline A13 & 7,20 & 3,00 & 0,29 \\
\hline A14 & 7,20 & 3,00 & 0,29 \\
\hline
\end{tabular}

In table 7 below the following ranking tables are used to determine employee performance appraisals for promotion every year. 
TABLE 7 VALUE RANKING

\begin{tabular}{|c|c|c|c|c|}
\hline Alternative & Positive & Negative & Preference & Rank \\
\hline A1 & 3,06 & 1,93 & 0,39 & 2 \\
\hline A2 & 3,31 & 1,35 & 0,29 & 8 \\
\hline A3 & 2,39 & 2,38 & 0,50 & 1 \\
\hline A4 & 5,95 & 1,78 & 0,23 & 14 \\
\hline A5 & 6,04 & 1,90 & 0,24 & 12 \\
\hline A6 & 5,99 & 1,83 & 0,23 & 13 \\
\hline A7 & 6,93 & 2,73 & 0,28 & 9 \\
\hline A8 & 6,90 & 2,71 & 0,28 & 10 \\
\hline A9 & 6,90 & 2,70 & 0,28 & 11 \\
\hline A10 & 7,14 & 2,94 & 0,29 & 6 \\
\hline A11 & 7,15 & 2,94 & 0,29 & 5 \\
\hline A12 & 7,13 & 2,93 & 0,29 & 7 \\
\hline A13 & 7,20 & 3,00 & 0,29 & 3 \\
\hline A14 & 7,20 & 3,00 & 0,29 & 4 \\
\hline
\end{tabular}

In table 7 it is concluded that the highest value is in code A3 on behalf of Ridan with a value of 0.50 as the first rank in Senayan Apartment Jakarta.

\section{CONCLUSION}

The conclusions from the research results are as follows:

1. This study uses the Topsis method. this method used to complete the selection of a number of alternatives based on several predetermined criteria.

2. This method is used at the Senayan Jakarta Apartment to assess the quality of employee performance for job promotion every year and determine eligible employees to be promoted to positions based on good performance based on specified criteria

3. Samples of data used by 14 employees obtained results based on ranking, namely employees on behalf of Ridan get the first rank with a value of 0.50 .

For the next research web or desktop applications are built to build a system that is more effective and efficient and uses other decision support methods.

\section{ACKNOWLEDGMENT}

Thank you to fellow lecturers of Bina Sarana Informatika University who have supported the research that has been done.

\section{REFERENCES}

Afandi, P. (2016). Concept \& indicator human resource management for management researth.
Yogyakarta: Deepublish (Group CV Budi Utama).

Herawatie, D., \& Wuryanto, E. (2017). Sistem pendukung keputusan pemilihan mahasiswa berprestasi menggunakan metode. Journal of Information Systems Engineering And Business Intelligence, 3(2), 92-100.

Kurniawan, H. (2015). Sistem Pendukung Keputusan Penilaian Kinerja Karyawan Menggunakan Metode Topsis Berbasis Web Pada CV . Surya Network Indonesia. Konferensi Nasional Sistem \& Informatika, 9-10.

Mallu, S. (2015). Sistem pendukung keputusan penentuan karyawan kontrak menjadi karyawan tetap menggunakan metode topsis. Jurnal Ilmiah Teknologi Informasi Terapan (Jitter), I(2), 36-42.

Nofriansyah, D. (2015). Konsep Data Mining Vs Sistem Pendukung Keputusan. Yogyakarta: Deepublish.

Nurhayati, S. (2017). Sistem Penilaian Kinerja Karyawan Menggunakan Metode Topsis pada PT XYZ Employee Performance Assessment System using Topsis Method in PT XYZ. Prosiding Saintiks Fakultas Teknik Dan Ilmu Komputer Unikom, 2, 25-28.

Sugiyono. (2016). Metode Penelitian Pendidikan Pendekatan Kuantitatif.

Yusnita, A., Salmon, \& Ramadhan, H. (2015). Sistem Pendukung Keputusan Penilaian Kinerja Karyawan Menggunakan Metode Topsis ( Technique for Others Reference By Similarity To Ideal Solution ) Pada Pt . Rio Utama Samarinda. Prosiding Seminar Ilmiah Nasional Teknologi Komputer (Senatkom 2015), 1(Senatkom), 84 89. 